\title{
ANALISIS ISI BUKU TEKS PELAJARAN \\ ILMU PENGETAHUAN SOSIAL KURIKULUM 2013 \\ KELAS VII SMP/MTS
}

Nur Achmad Prihantoro, Prof. Dr. Warsono, MS, Prof. Dr. Sunarto, M.Sc

\begin{abstract}
Abstrak
Penelitian ini bertujuan untuk mendeskripsikan kelayakan buku teks pelajaran melalui analisis isi pada buku teks pelajaran Ilmu Pengetahuan Sosial Kurikulum 2013 kelas VII SMP/MTs. Metode yang digunakan dalam penelitian ini adalah menggunakan pendekatan kualitatif dengan jenis penelitian analisis isi (content analysis). Alasan menggunakan metode analisis isi adalah bahwa peneliti ingin mengungkapkan tentang kelayakan sebuah buku teks pelajaran IPS yang diterbitkan oleh penerbit diluar Kementerian pendidikan dan kebudayaan apakah sudah sesuai dengan standar kelayakan dari BSNP, yang terdiri dari kelayakan materi/isi, kelayakan penyajian, kelayakan Bahasa, dan kelayakan kegrafikaan. Selain itu peneliti ingin mendeskripsikan apakah materi dalam buku tersebut sudah sesuai dengan kriteria keterpaduan dalam pembelajaran IPS. Data hasil penelitian yang diperoleh sebagai berikut: aspek kelayakan isi, uraian materi sudah sesuai dengan KI dan KD, keakuratan materi,kemutakhiran materi, mendorong keingintahuan, dan peluasan wawasan sudah dengan standar kelayakan dari BSNP. Aspek kelayakan penyajian yang terdiri dari teknik penyajian, pendukung penyajian, dan penyajian pembelajaran sudah sesuai dengan standar kelayakan. Sedangkan untuk aspek kelayakan Bahasa sebagian besar sudah layak dan aspek yang keempat yaitu kegrafikaan, mulai dari ukuran buku, desain kulit buku dan desain isi buku, juga telah memenuhi standar kelayakan kegrafikan yang telah ditentukan oleh BSNP. Materi yang terdapat pada buku tersebut juga sudah sesuai dengan kaidah keterpaduan dalam pembelajaran IPS. Berdasarkan hasil analisis data, dapat disimpulkan bahwa buku teks pelajaran Ilmu Pengetahuan Sosial Kurikulum 2013 kelas VII SMP/MTs terbitan Platinum sudah sesuai dengan standar kelayakan dari BSNP dan layak dipakai di sekolah-sekolah, namun masih memerlukan sedikit perbaikan pada beberapa bagian.
\end{abstract}

Kata-kata Kunci: Analisis Isi, buku teks pelajaran, Ilmu Pengetahuan Sosial, Kurikulum 2013

Abstract

This study aims to describe the appropriateness of textbook lessons through the analysis of the contents on a textbook lesson in Social Science Curriculum 2013 at Class VII SMP/MTs. The method used in this research is the use of qualitative approach with the types of content analysis research (content analysis). That researcher wants to express about the feasibility of a textbook lesson on IPS that is published by publishers outside of the Ministry of education and culture is already in compliance with standards of eligibility from BSNP, comprising the feasibility of material/content, presentation of feasibility, appropriateness and feasibility of graphics. In addition researcher likes to describe whether the material in the book is in compliance with criteria alignment in the IPS study. The data of the research results obtained are as follows: the feasibility aspect contents, description of materials are in accordance with KI and KD, the accuracy of the material, the material date, encourage curiosity, and extensions of the insights already with standard feasibility of BSNP. Feasibility aspect presentation consists of a technique of presentation, presentation and supporting learning in compliance with the standards of eligibility. As for the feasibility aspect of language and most of the fourth aspect, namely graphics, ranging from the size of the book, skin design books and design content, the eligibility standards have also been graphics ass they been determined by BSNP. Material content of the book are also in accordance with the rules of alignment in IPS study. Based on the results of data analysis, it can be inferred that a textbook lesson in Social Science Curriculum 2013 at Class VII SMP/MTs issue Platinum is in compliance with the standards of eligibility from BSNP and decent used in schools, but it still needs a little improvement on some parts.

Keywords: Analysis of the contents, textbook lesson, social science, curriculum 2013 


\section{PENDAHULUAN}

PBB melalui Unesco mengutarakan tentang empat pilar belajar. paradigma pembelajaran menurut UNESCO akan menciptakan proses belajar-mengajar yang efektif, yaitu : belajar mengetahui (learning to know), belajar bekerja (learning to do), belajar hidup bersama (learning to live together), dan belajar menjadi diri sendiri (learning to be).

Learning to know memiliki pengertian bahwa ketika kita belajar kita akan menjadi tahu, Bahasa mudahnya dari mulai tidak tahu menjadi tahu. Learning to do maksudnya setelah kita mengetahui hal-hal yang baru dari pembelajaran yang kita lakukan, kita bisa melakukan sesuatu karya atau bentuk pekerjaan nyata dari ilmu yang telah diserap. Learning to live together maksudnya dengan kita mengetahui dan kita dapat melakukan sesuatu dari apa yang kita pelajari, selanjutnya kita dapat melakukannya untuk diri kita sendiri dan juga untuk orang lain yang ada di sekitar kita. Sedangkan Learning to be ini maksudnya adalah setelah kita mengetahui, kita dapat melakukan, kita dapat membaginya dengan orang lain, kita dapat membuat sesuatu yang lebih baik. Baik itu bagi diri kita sendiri maupun orang lain.

Pendidikan merupakan salah satu aspek penting yang sangat berperan dalam pembangunan suatu bangsa. Pemerintah yang sejak dulu menyadari akan peran pendidikan yang begitu penting bagi pembangunan dan kemajuan bangsa, dalam Pembukaan UUD Tahun 1945 Tahun 1945 yang menegaskan bahwa salah satu tujuan Proklamasi Kemerdekaan Negara Kesatuan Republik Indonesia adalah mencerdaskan kehidupan bangsa yang dapat diwujudkan melalui pendidikan. Menurut pasal 31 dalam Undang-Undang Dasar 1945 tentang pendidikan yang berbunyi (1) tiap-tiap warga negara berhak mendapat pengajaran; (2) pemerintah mengusahakan dan menyelenggarakan satu sistem pengajaran nasional, yang diatur dengan undang-undang.

Salah satu tujuan dari pembelajaran Ilmu Pengetahuan Sosial adalah "to promote Civic Competence" yang dapat diartikan mengembangkan kemampuan warga Negara, hal tersebut sejalan dengan yang didefinisikan oleh National Council for the Social Studies (NCSS). Focus pembelajarannya adalah untuk membantu kaum muda membuat informasi dan keputusan yang beralasan untuk kepentingan publik sebagai warga masyarakat yang beragan budaya serta masyarakat yang demokratis di dunia yang saling tergatung. Dengan pemahaman tersebut, pembelajaran IPS sangat penting dalam membentuk karakter sebuah bangsa serta menyiapkan generasi muda sebagai warga Negara yang berada.

Melalui pembelajaran IPS diharapkan siswa tidak hanya mampu menguasai teori teori kehidupan di dalam masyarakat tapi mampu menjalani kehidupan nyata di masyarakat sebagai insan sosial. warga negara yang mampu mengaplikasikan ilmunya dalam bentuk amalan nyata yang bermanfaat bagi kehidupan di masyarakat. Padahakekatnya manusia selain sebagai makhluk yang harus mengenal dirinya, juga sebagai makhluk sosial, yang harus mampu hidup berinteraksi dengan manusia lainnya yakni dalam kehidupan masyarakat.

Kunci utama dalam pembelajaran IPS adalah bagaimana membina kecerdasan sosial siswa yang mampu berpikir kritis, analitis, kreatif, inovatif, berwatak dan berkepribadian luhur, bersikap ilmiah dalam cara memandang, menganalisa serta menelaah kehidupan nyata yang dihadapinya, (Badan Standar Nasional Pendidikan 2006).

Tujuan IPS lebih menekankan pada pengetahuan tentang bangsanya, semangat kebangsaan, patriotisme, serta aktivitas masyarakat di bidang ekonomi dalam ruang wilayah Negara kesatuan Republik Indonesia. Dalam pelaksanaan kegiatan pembelajarannya, peserta didik lebih diarahkan untuk memiliki kemampuan berpikir, kemampuan belajar, rasa ingin tahu, pengembangan sikap peduli dan bertanggung jawab terhadap lingkungannya.

Dalam Kurikulum 2013, Ilmu Pengetahuan Sosial (IPS) dikembangkan secara terpadu, tidak dipisah dalam kelompok geografi, sejarah, ekonomi, dan sosiologi. Pembelajaran IPS diintegrasikan melalui konsep ruang, koneksi antar ruang dan waktu. Ruang adalah tempat manusia beraktivitas, koneksi antar ruang menggambarkan mobilitas manusia antara satu tempat ke tempat lain, dan waktu menggambarkan masa dimana kehidupan manusia itu terjadi. Walaupun disusun secara terpadu, namun geografi dijadikan sebagai platform kajian dengan pertimbangan semua kejadian dan kegiatan terikat dengan lokasi tujuannya adalah menekankan pentingnya konektivitas ruang dalam memperkokoh NKRI. Kajian sejarah, sosiologi, budaya dan ekonomi disajikan untuk mendukung terbentuknya konektivitas yang lebih kokoh.

Dalam pelaksanaan kurikulum 2013 yang baru ini, terdapat beberapa permasalahan yang menyebabkan pembelajaran dengan menggunakan kurikulum 2013 yang digadang-gadang merupakan kurikulum revolusioner yang nantinya dapat meningkatkan dunia pendidikan di Indonesia setelah berkali-kali bergonta- 
ganti kurikulum untuk mencari sebuah kurikulum yang tepat untuk digunakan dalam dunia pendidikan kita.

Salah satu permasalahan yang terjadi dalam pelaksanaan pembelajaran kurikulum 2013 khususnya mata pelajaran IPS adalah ketersediaan buku teks IPS berbasis kurikulum 2013 yang akan dipakai dalam proses pembelajaran. Buku merupakan salah satu sumber belajar yang penting bagi guru dan peserta didik. Buku teks juga merupakan salah satu media pendidikan yang kedudukannya strategis dan ikut mempengaruhi mutu pendidikan, karena dapat berfungsi sebagai sumber belajar dan media yang sangat penting untuk mendukung tercapainya kompetensi yang menjadi tujuan pembelajaran.

Menurut Banowati ( 2007: 147) "Keberadaan buku teks sangat diperlukan dalam proses pembelajaran, seharusnya buku teks yang digunakan dapat menunjang dalam peningkatan hasil belajar dan mencerdaskan bangsa dalam hal ini adalah pelajar". Selain sebagai bahan yang berisi materi pelajaran, buku teks digunakan sebagai acuan dalam mencapai tujuan belajar. Bagi guru, selain sebagai buku pegangan, buku teks juga digunakan sebagai alat untuk memantau seberapa jauh ketercapaian siswa dalam mengikuti pelajaran, sedangkan bagi siswa buku teks dapat dijadikan teman belajar ketika tidak sedang berada dalam lingkungan kelas. Keterbatasan waktu tatap muka membuat siswa harus berupaya memperkaya pengetahuan melalui berbagai sumber. Salah satunya melalui buku teks.Oleh karena itu, mengingat pentingnya peranan buku teks, hendaknya setiap buku teks harus memenuhi criteria yang sesuai dengan standar dalam pembelajaran.

Dalam upaya perwujudan tercapai tujuan pendidikan serta memenuhi standar yang ditetapkan dalam kurikulum antara lain dibutuhkannya buku teks pelajaran. Buku teks pelajaran digunakan sebagai fondasi atau bahan pokok dalam menyampaikan berbagai kompetensi yang akan dicapai. Buku teks merupakan salah satu sarana yang sering digunakan oleh setiap guru dalam proses pembelajaran. Buku teks dijadikan sebagai bahan pokok selain bahan tambahan lain untuk memperkaya referensi. Oleh karena itu, buku teks memiliki peranan yang sangat penting dalam pembelajaran tak terkecuali matapelajaran IPS.

Sebuah buku teks tidak hanya dapat ditelaah dari segi nilai yang terkandung di dalamnya, melainkan juga dapat ditelaah dari segi jangkauan materinya. Buku teks merupakan salah satu komponen dari alat-alat pengajaran yang menentukan kualitas pendidikan. Sehingga peserta didik wajib mempunyai buku teks untuk membantu proses pembelajaran dan meningkatkan prestasi hasil belajar. Dengan meningkatnya prestasi belajar peserta didik akan sebagai indikator meningkatnya mutu pendidikan.

Seperti diketahui bahwa perubahan kurikulum pembelajaran di Indonesia selalu menjadi kontroversi. Jadi, keberhasilan kurikulum 2013 nantinya juga akan sangat dipengaruhi oleh buku-buku teks yang menjadi pedoman bagi pelaksanaan pembelajaran menggunakan kurikulum 2013 supaya tidak bernasib sama dengan kurikulum pendahulu-pendahulunya.

Contoh-contoh seputar permasalahan yang terjadi pada buku teks adalah: (1) buku teks terlalu banyak jenisnya sehingga sering membingungkan siswa dalam memilih buku teks yang tepat, (2) buku teks kurang meningkatkan kreatifitas guru dan siswa dalam proses pembelajaran karena hanya terpaku pada materi yang ada pada buku teks, (3) buku teks sering kali menjadi bahan tugas guru kepada siswanya ketika guru malas untuk mengajar, (4) isi dari buku teks yang selama ini digunakan dalam proses pembelajaran sering kali tidak sesuai dengan kurikulum yang berlaku, (5) buku teks dijadikan ladang bisnis bagi pihak ketiga, (6) penggunaan buku teks tidak merata pada setiap lembaga pendidikan/sekolah, (7) buku teks memilki harga yang lebih mahal siswa cenderung menggunakan LKS karena harga yang lebih terjangkau, (8) buku teks kurang mengembangkan kemampuan guru dalam menyapaikan materi dan lebih terpaku pada apa yang tertulis pada buku teks, (9) bahasa yang digunakan dalam buku teks terkadang sulit dipahami oleh siswa, (10) konten dari buku teks ini terkadang tidak sesuai dengan usia penggunanya/siswa, (11) soal-soal dalam buku teks cenderung monoton dan sulit untuk dijawab, (12) konsep dalam buku teks cenderung lebih rumit tapi berpotensi timbulnya miskonsepsi baik pada siswa maupun gurunya, (13) banyak ditemukan kesalahan dalam isi buku teks, misalnya kesalahan ketikan.

\section{METODE}

Penelitian ini menggunakan pendekatan kualitatif dengan analisis konten yang berusaha untuk memahami pesan simbolik pada sebuah dokumen. Dokumen yang dianalisis adalah buku teks siswa matapelajaran Ilmu Pengetahuan Sosial kurikulum 2013 untuk SMP/MTS kelasVII.

Analisis konten merupakan teknik penelitian untuk membuat inferensi yang dapat diteliti ulang dan valid dari data berdasarkan konteks penggunaannya, sesuai dengan Krippendorf (2004: 18) yang mendefinisikan "Content analysis is a research technique for making replicable and valid inferences from texts (or other meaningful matter) to the contexts of their use".

Penelitian analisis isi adalah sebuah metode yang berfokus pada konten yang sebenarnya dan tema 
dari sebuah teks.. Jadi penelitian analisis konten adalah penelitian yang dilakukan dengan mengkaji teks, dokumen atau buku guna mengambil kesimpulan (inferensi) berdasarkan konteks penggunaannya. sumber datanya adalah dokumen-dokumen berupa buku teks pelajaran IPS kurikulum 2013 kelas VII SMP/MTs.

Penelitian ini dilaksanakan pada bulan Maret 2016hingga bulan juni 2016. Sedangkan Teknik pengumpulan data yang digunakan dalam penelitian ini adalah pembacaan dan pencatatan yang cermat terhadap buku teks pelajaran IPS kurikulum 2013 kelas VII SMP/MTS. Instrumen utama yang akan digunakan dalam penelitian ini adalah human instrument yaitu peneliti sendiri. Dengan pengetahuan, ketelitian dan kekritisan peneliti mencari dan menggali untuk menemukan data-data yang diperlukan sesuai dengan permasalahan penelitian. Untuk memudahkan peneliti mengkategorikan data yang terkumpul, peneliti menggunakan instrumen.

Agar memperoleh pemahaman yang mendalam dan tajam tentang aspek penyajian dalam buku teks pelajaran, penelitian ini menggunakan kriteria yang disusun oleh BNSP untuk buku teks pelajaran IPS, yaitu: aspek isi/materi, aspek penyajian, aspek bahasa, dan aspek kegrafikaan. Selain itu juga akan dianalisi aspek keterpaduan IPS yang terdapat dalam buku tersebut.

Adapun teknik analisis data yang akan digunakan pada penelitian ini adalah skema analisis konten menurut Krippendorf (2004: 83), adalah: unitizing (pengumpulan data), sampling (penentuan Sampel), recording (perekaman/pencatatan). reducing (reduksi). Inferring (penarikan kesimpulan).

\section{HASIL DAN PEMBAHASAN}

Penelitian ini bertujuan untuk mendeskripsikan kelayakan buku teks pelajaran melalui analisis isi pada buku teks pelajaran Ilmu Pengetahuan Sosial Kurikulum 2013 kelas VII SMP/MTs terbitan Platinum. Berikut ini merupakan deskripsi hasil penelitian yang telah dilakukan.

\section{A. Diskusi Analisis Isi Kelayakan Materi/Isi Buku Teks Pelajaran Ilmu Pengetahuan Sosial Kelas VII SMP/MTs Kurikulum 2013}

Berdasarkan hasil analisis isi kelayakan isi/materi pada subkomponen dan deskripsi dari butir yang dianalisis maka untuk aspek kelayakan materi/isi terdiri yang dari lima subkomponen. Yaitu, kesesuaian uraian materi dengan KI dan KD, keakuratan materi, kemutakhiran materi, mendorong keingintahuan, peluasan wawasan, dapat di diskusikan sebagai berikut.

Dalam subkomponen kesesuaian uraian materi dengan KI dan KD pada buku teks pelajaran IPS untuk SMP/MTs kelas VII ini telah memiliki materi yang sudah sesuai dengan Kompetensi Dasar (KD) dan Kompetensi
Dasar (KD) IPS kelas VII. Sehingga kesesuaian ini mendukung untuk tercapainya KI dan KD. Materi yang ada didalam buku ini sudah menggunakan kurikulum 2013 memiliki cakupan materi yang cukup, dalam penulisan materi buku ini tidak dipaparkan secara mendalam, karena uraian materi didalam buku kurang menjabarkan untuk menggali kedalaman isi materi, jika materi lebih diluaskan lagi siswa akan memiliki pengetahuan yang lebih. Secara keseluruhan buku ini sudah cukup baik, karena KI dan KD berhubungan erat dengan isi materi. Keterpaduan KI dan KD, materi mengarah untuk tercapainya materi pokok pembelajaran.

Menurut Peraturan Pemerintah nomor 32 tahun 2013 tentang standar nasional pendidikan, pasal 1 ayat 23, "buku teks pelajaran adalah sumber pembelajaran utama untuk mencapai kompetensi dasar dan kompetensi inti”. Lalu menurut Muslich (2010: 50) mendefinisikan "buku teks atau buku pelajaran sebagai buku sekolah yang memuat bahan yang telah diseleksi mengenai bidang studi tertentu, dalam bentuk tertulis yang memenuhi syarat tertentu dalam kegiatan belajar mengajar, dan disusun secara sistematis untuk diasimilasikan" .Selain itu, menurut Heedgock \& Ferris (2009: 138) menyatakan bahwa "buku teks pelajaran dapat dijadikan sebagai referensi pokok dalam menginterpretasikan kurikulum". Dari ketiga pendapat tersebut sesuai dengan butir penilaian yang pertama yaitu kesesuaian Uraian materi dengan ki dan kd.

Pada komponen keakuratan Materi didalam buku teks pelajaran yang baik harus memiliki keakuratan dan terkonsep dalam satu buku yang tidak menimbulkan banyak definisi, sehingga tidak membuat bingung siswa untuk memahami, begitu pula pada buku teks pelajaran ini disusun dengan sederhana, materi sekaligus informasi yang disajikan sesuai dengan fakta dan data, keakuratan materi buku ini seperti yang terdapat pada tema 4 tentang keragaman sosial dan budaya indonesia, dalam satu tema dengan sub tema memiliki berbagai pembahasan, namun masih dalam satu tema yaitu keragaman sosial dan budaya yang disajikan sesuai fakta dan data. Selain itu di buku ini kesesuaian dan ketelitian contoh soal dan soal latihan yang dipergunakan beberapa sudah sesuai dengan konteks materi pembahasan.

Pada materi yang dibahas juga terdapat gambar, ilustrasi yang sesuai dengan bacaan atau konteks materi. Namun terdapat beberapa gambar yang, diagram atau ilustrasi yang tidak mencantumkan sumbernya, seperti pada halaman 15,16,20,21,29. Kesesuaian daftar pustaka dengan materi pada buku ini yaitu daftar pustaka mencantumkan pustaka yang sesuai dengan konteks materi buku atau tidak terdapat pustaka dalam daftar pustaka yang tidak sesuai dengan konteks. Pada buku ini juga seluruh pustaka yang terdapat dalam daftar pustaka telah digunakan sebagai acuan dalam teks.

Menurut Tarigan (2009: 19) "buku pelajaran memiliki aneka fungsi, antara lain (1) mencerminkan suatu sudut pandang, (2) menyediakan suatu sumber yang teratur, rapi dan bertahap, (3) menyajikan pokok masalah yang kaya dan rapi, (4) menyajikan aneka metode dan sarana pengajaran, (5) menyajikan fiksasi awal bagi tugas dan latihan, dan (6) menyajikan sumber bahan evaluasi 
dan remedial". Sedangkan oleh Muslich (2010: 56) menyatakan bahwa "pelajaran dalam kelas sangat bergantung dengan buku teks. Buku teks merupakan pembimbing dan penunjang dalam mengajar. Bagi peserta didik, buku teks sebagai dasar untuk belajar sistematis, untuk memperteguh, mengulang, dan mengikuti pelajaran lanjutan". Menurut Sitepu (2009: 21) "Buku teks pelajaran berfungsi sebagai pedoman manual bagi siswa dalam belajar dan bagi guru dalam membelajarkan siswa untuk bidang studi atau mata pelajaran tertentu". Pedoman belajar bagi siswa berarti siswa menggunakannya sebagai acuan utama dalam, (1) mempersiapkan diri secara individu atau kelompok sebelum kegiatan belajar di kelas, (2) berinteraksi dalam proses pembelajaran di kelas, (3) mengerjakan tugastugas yang diberikan guru, dan (4) mempersiapkan diri untuk tes atau ujian formatif dan sumatif.

Pada subkomponen kemutakhiran materi dalam buku ini beberapa materi yang disajikan mengacu pada teori, peraturan, dan perundang-undangan yang masih berlaku contohnya UU RI No. 19 tahun 2003 tentang BUMN. Banyak contoh soal dan kasus actual yang terdapat didalam buku ini sesuai dengan kondisi serta situasi dan benar-benar terjadi di Indonesia, misalnya pada halaman 233 dengan materi dampak aktivitas manusia terhadap lingkungan social budaya, pembahasan materi tersebut berisi tentang gaya rambut dan pakaian Anak Band Indonesia yang sedang naik daun yang meniru gaya dari band-band jepang. Sedangkan untuk kemutakhiran pustaka pada buku ini adalah bahwa terdapat sangat banyak pustaka yang digunakan tidak mutakhir dengan batas kemutakhiran 5 tahun. Yaitu dari 43 daftar pustaka yang ada di buku ini, sebanyak 35 pustaka terbitan dibawah tahun 2008

Byrd (2001: 416) menyebutkan beberapa hal yang perlu guru pertimbangkan dalam memilih buku pelajaran, yaitu: (1) kesesuaian antara buku dan kurikulum, (2) kesesuaian antara teks/isi buku dengan siswa, misal isi buku menariksiswa, penjelasan buku sesuai dengan tujuan pembelajaran yang direncanakan, contoh materi sesuai isi/penjelasan, tugas sesuai dengan karakteristik/gaya belajar siswa, ilustrasi buku sesuai dengan usia siswa, teks atau tulisan dalam buku mudah dibaca dan sesuai dengan tingkat membaca, buku memiliki indeks, apendiks, dan hal lain yang diperlukan siswa, (3) kesesuaian antara teks/isi buku dengan guru, misal guru memiliki kemampuan untuk memahami isi materi tersebut dan mampu menjelaskan pada siswa, isi buku berisikan materi yang sesuai dengan tujuan pembelajaran yang diinginkan oleh gurudapat dicapai oleh siswa, terdapat panduan bagi guru delam menggunakan buku, buku dilengkapi dengan alat penunjang seperti kaset/cd, contoh materi dapat digunakan dan disusun kembali oleh guru, latihan/tugas dalam buku sesuai dengan waktu yang direncanakan guru, dan menyediakan berbagai aktivitas yang sesuai dengan gaya belajar siswa, dan ilustrasi buku ada hubungan dengan isi buku.

Pada subkomponen mendorong keingintahuan. Sangat banyak uraian, contoh latihan dan kasus yang disajikan pada buku ini yang dapat mendorong siswa untuk berusaha mencari informasi lebih jauh tentang materi yang disajikan dan contoh kasus lain yang dapat memperluas pemahaman, wawasan atau meningkatkan ketrampilan. Hal ini bias dilihat kolom tugas individu, kolom renungkan, kolom aktivitas kelompok, dan kolom uji kompetensi di setiap akhir sub tema/subbab.

Sesuai dengan pendapat Greene dan Petty (dalam Tarigan, 2009: 20) terdapat 10 kriteria yang harus dipenuhi untuk buku teks yang berkualitas sebagai berikut.

a. Buku teks harus menarik minat anak-anak.

b. Buku teks harus mampu memberi motivasi bagi siswa.

c. Buku teks juga harus memuat ilustrasi yang menarik hati para siswa-siswanya.

d. Buku teks seyogyanya harus mempertimbangkan aspek-aspek linguistic.

e. Buku teks juga haruslah berhubungan erat dengan pelajaran-pelajaran lainnya.

f. Buku teks juga harus menstimulasi, merangsang aktivitasaktivitas pribadi para siswa.

g. Buku teks haruslah dengan sadar dan tegas menghindari konsep-konsep yang samarsamar.

h. Buku teks juga harus mempunyai sudut pandang yang jelas dan tegas sehingga juga pada akhirnya menjadi sudut pandangan para pemakainya yang setia.

i. Selain itu buku teks haruslah mampu memberi pemantapan penekanan nilai-nilai anak dan orang dewasa.

j. Buku teks harus menghargai perbedaanperbedaan pribadi para siswa dan pemakaiannya.

Dalam subkompone peluasan wawasan, buku teks pelajaranIPS kelas VII ini, didalamnya tidak hanya berisi materi saja, tetapi juga berisi contoh-contoh yang memberikan gambaran hubungan Antara materi dalam KI dan KD dengan aktivitas ataupun peristiwa lain tetapi selalu dengan bidang yang sama yaitu sosial.

\section{B. Diskusi Isi Kelayakan Penyajian Buku Teks Pelajaran Ilmu Pengetahuan Sosial Kelas VII SMP/MTs Kurikulum 2013}

Berdasarkan hasil analisis isi kelayakan penyajian pada subkomponen dan deskripsi dari butir yang dianalisis maka untuk aspek kelayakan penyajian yang terdiri dari empat subkomponen. Yaitu, teknik penyajian, pendukung penyajian, penyajian pembelajaran, koherensi dan keruntutan alur pikir, dapat didiskusikan sebagai berikut.

Pada subkomponen teknik penyajian, konsistensi sistematika penyajian dalam buku ini cukup baik, mulai dari pendahuluan yang berisi kata pengantar, daftar isi, dan standar isi. Kemudian bagian isi meliputi uraian, wacana, pelatihan, ilustrasi, gambar dan lainnya. Hingga bagian penutup juga ada pada semua tema, sehingga bisa dikatakan bahwa sistematika penyajian pada buku ini dalam setiap tema taat asas yang terdiri 
dari pendahuluan,isi, dan penutup. Dari segi keruntutan materi. Dalam buku teks ini satu atau dua bab/tema disajikan secara tidak runtut karena ada materi dalam setiap bab yang tidak disajikan secara runtut mulai dari yang mudah ke sukar, sederhana ke kompleks, dikenal sampai yang belum dikenal atau materi bagian sebelumnya kurang membantu pemahaman materi pada bagian selanjutnya, seperti pada tema 1 dan tema 3 . Namun pada buku ini penyampaian pesan Antara subbab dan antar alinea dalam subbab yang berdekatan mencerminkan keruntutan dan keterkaitan isi atau. Dalam buku ini terdapat uraian singkat tentang materi-materi yang akan dibahas pada setiap bab. Hingga terdapat rangkuman yang berisi $50 \%$ atau lebih materi subbab dalam setiap bab yang bersangkutan yang dinyatakan dengan kalimat ringkas dan jelas.

Untuk subkomponen pendukung penyajian, pada buku ini telah mengikuti kaidah penulisan kutipan yang berlaku dan menggunakannya secara konsisten sehingga jarang terdapat kesalahan cara pengutipan ,misalnya pada halaman 231. Pada buku ini juga terdapat pengantar di bagian awal buku yang memuat tujuan penulisan buku, sistematika penulisan dan materi kunci. Lalu terdapat daftar isi ringkas dan daftar isi rinci pada bagian awal buku yang memuat judul subbab dan sub-sub dibawahnya. Juga terdapat Glosarium untuk beberapa istilah kunci dalam teks dengan penjelasa arti istilah tersebut (25 istilah), daftar indeks untuk beberapa kata/istilah kuci juga ada walaupun tidak banyak. Sedangkan daftar pustaka yang digunakan sebagai bahan rujukan pada buku teks IPS ini sudah disusun menurut aturan yang baku dan digunakan secara konsisten.

Pada subkomponen penyajian pembelajaran ,buku IPS ini sudah memasukkan unsur keterlibatan peserta didik, yaitu terdapat bagian yang mengajak peserta didik untuk melakukan aktivitas bersama, misalnya dengan mengajak peserta mencoba latihan dengan menggunakan data baru dengan cara diskusi atau kerjasama seperti yang terdapat pada kolom aktivitas kelompok yang terdapat pada seluruh tema di buku ini.

Pada subkomponen koherensi dan keruntutan alur pikir yang berhubungan dengan penyampaian pesan antara sub bab dengan bab lain, sub bab dengan sub bab. Buku yang kami analisis ini sudah menunjukan hal tersebut, Keutuhan makna dalam tema, subtema, alenia didalam buku ini sudah menjelaskan dan mencerminkan pesan atau materi yang disajikan dalam satu tema. Misalnya salah satu tema yaitu tema 3 "Penduduk Indonesia dan pemanfaatn potensi sumber daya alam" dengan sub-sub tema dibawahnya yaitu, keadaan penduduk Indonesia, pertumbuhan persebaran dan proyeksi penduduk, kualitas penduduk Indonesia, pemanfaatan sumber daya alam, potensi alam dan mobilitas penduduk antar wilayah di Indonesia, lembagalembaga sosial. Dari tema, sub tema, alenia berhubungan dalam satu tema, yaitu tentang penduduk dan sumber daya alam.

Dalam aspek kelayakan penyajian ini beberapa butir analisis dan deskripsiinya sesuai dengan pendapat dari Muslich (2010: 50) yang mendefinisikan "buku teks atau buku pelajaran sebagai buku sekolah yang memuat bahan yang telah diseleksi mengenai bidang studi tertentu, dalam bentuk tertulis yang memenuhi syarat tertentu dalam kegiatan belajar mengajar, dan disusun secara sistematis untuk diasimilasikan". Bahwa pelajaran dalam kelas sangat bergantung dengan buku teks. Buku teks merupakan pembimbing dan penunjang dalam mengajar. Bagi peserta didik, buku teks sebagai dasar untuk belajar sistematis, untuk memperteguh, mengulang, dan mengikuti pelajaran lanjutan.

\section{Diskusi Isi Kelayakan Bahasa Buku Teks Pelajaran Ilmu Pengetahuan Sosial Kelas VII SMP/MTs Kurikulum 2013}

Berdasarkan hasil analisis isi kelayakan bahasa pada subkomponen dan deskripsi dari butir analisis maka untuk aspek kelayakan penyajian yang terdiri dari tiga subkomponen yaitu kesesuaian dengan tingkat perkembangan peserta didik, komunikatif, tata bahasa, ejaan, istilah, simbol.

Pada subkomponen kesesuaian dengan tingkat perkembangan peserta didik. Buku teks pelajaran haruslah menyesuaikan dengan perkembangan siswa atau ditingkat jenjang yang sesuai dengan buku ini, yaitu tingkat SMP. Bahasa didalam buku ini sederhana sesuai dengan tingkat kemampuan dan pengetahuan siswa SMP, penjelasan konsep sesuai dengan perkembangan kognitif siswa. Bahasa yang digunakan dalam buku teks sudah menjelaskan konsep sampai dengan contoh yang abstrak sesuai dengan tingkat intelektual peserta didik yaitu yang secara imajinatif dapat dibayangkan oleh peserta didik. Bahasa yang digunakan sesuai dengan kematangan sosial emosional peserta didik atau bisa dikatakan dalam buku teks pelajaran IPS ini semua menggunakan kalimat yang sederhana, langsung pada inti pembahasan, tidak terlalu banyak menggunakan kalimat majemuk bertingkat atau kalimat majemuk bertaraf.

Untuk subkomponen komunikatif disini maksudnya adalah ketepatan tata bahasa, ejaan, dan kosakata yang dideskrIPSikan sebagai jumlah kesalahan penggunaan tata bahasa dan ejaan serta pencetakan miring istilah asing. dibuku ini setelah di analisis, tidak ditemukan atau tidak terdapat kesalahan penggunaan tata bahasa dan ejaan serta pencetakan miring untuk istilah asing. Sedangkan untuk konsistensi penggunaan istilah. Setelah dianalisa, sebagian besar istilah-istilah yang ada dalam buku sudah digunakan secara konsisten. Begitu pula dengan keterbacaan pesan. Pada buku teks pelajaran IPS ini pesan atau informasi yang disampaikan pada beberapa bab/tema disampaikan dengan bahasa yang mudah dipahami dan lazim dalam komunikasi tulis Bahasa Indonesia.

Untuk ketepatan struktur kalimat dan keefektifan kalimat pada buku teks pelajaran IPS ini setelah dianalisis adalah kalimat yang dipakai pada sebagian besar sudah mewakili isi pesan atau informasi yang ingin disampaikan tata kalimat Bahasa Indonesia yang benar, dan juga sebagian besar kalimat yang digunakan untuk menjelaskan materi menggunakan kalimat yang sederhana (tidak mengandung banyak anak kalimat) dan langsung pada inti bahasan. 
Untuk subkomponen tata bahasa, ejaan, istilah, dan simbol terdiri dari lima butir instrumen analisis yaitu ketepatan tata bahasa, ketepatan ejaan, kebakuan istilah, konsistensi penggunaan istilah, dan konsistensi penggunaan simbol. Pada ketepatan bahasa, sebagian besar tata bahasa pada buku teks IPS ini yang digunakan untuk menyampaikan pesan sudah mengacu pada kaidah tata Bahasa Indonesia yang baik dan benar. Pada penilaian ketepatan ejaan, sebagian besar ejaan yang digunakan juga sudah mengacu pada pedoman ejaan yang disempurnakan (EYD).

Untuk kebakuan istilah, setelah dianalisis bisa dikatakan bahwa sebagian besar istilah yang digunakan sudah sesuai dengan kamus besar Bahasa Indonesia (KBBI) dan/atau istilah teknis yang telah baku dalam IPS. Lalu pada penilaian konsistensi penggunaan istilah, sebagian besar penggunaan istilah yang menggambarkan konsep secara konsisten. Sedangkan pada konsistensi penggunaan simbol hasilnya adalah semua penggunaan simbol sudah dilakukan secara konsisten pada buku teks IPS ini.

Dalam aspek kelayakan bahasa, dari beberapa subkomponen dan butir analisis sesuai dengan pendapat Abdul Majid (2006: 176) memapaparkan bahwa "buku yang baik adalah buku yang ditulis dengan menggunakan bahasa yang baik dan mudah dimengerti, disajikan secara menarik dilengkapi dengan gambar dan keteranganketerangannya, isi buku juga menggambarkan sesuatu yang sesuai dengan ide penulisnya".

$$
\text { Kemudian menurut Byrd (2001: 416) }
$$
menyebutkan beberapa hal yang perlu guru pertimbangkan dalam memilih buku pelajaran yaitu: (1) kesesuaian antara buku dan kurikulum, (2) kesesuaian antara teks/isi buku dengan siswa, misal isi buku menariksiswa, penjelasan buku sesuai dengan tujuan pembelajaran yang direncanakan, contoh materi sesuai isi/penjelasan, tugas sesuai dengan karakteristik/gaya belajar siswa, ilustrasi buku sesuai dengan usia siswa, teks atau tulisan dalam buku mudah dibaca dan sesuai dengan tingkat membaca, buku memiliki indeks, apendiks, dan hal lain yang diperlukan siswa, (3) kesesuaian antara teks/isi buku dengan guru, misal guru memiliki kemampuan untuk memahami isi materi tersebut dan mampu menjelaskan pada siswa, isi buku berisikan materi yang sesuai dengan tujuan pembelajaran yang diinginkan oleh gurudapat dicapai oleh siswa, terdapat panduan bagi guru delam menggunakan buku, buku dilengkapi dengan alat penunjang seperti kaset/cd, contoh materi dapat digunakan dan disusun kembali oleh guru, latihan/tugas dalam buku sesuai dengan waktu yang direncanakan guru, dan menyediakan berbagai aktivitas yang sesuai dengan gaya belajar siswa, dan ilustrasi buku ada hubungan dengan isi buku.

\section{Diskusi Isi Kelayakan Kegrafikaan Buku Teks Pelajaran Ilmu Pengetahuan Sosial Kelas VII SMP/MTs Kurikulum 2013}

Berdasarkan hasil analisis isi kelayakan kegrafikaan pada subkomponen dan deskripsi butir analisis maka untuk aspek kelayakan penyajian terdiri dari tiga subkomponen yaitu ukuran buku, desain kulit buku, dan desain isi buku.

Ukuran buku Teks IPS Kurikulum 2013 Kelas VII SMP/MTs penerbit Platinum ialah A4 (201 x 297 $\mathrm{mm})$. Menurut penulis, kesesuaian ukuran buku dengan materi yang ada dalam buku tersebut telah bisa dikatakan sesuai dengan standar yang ada.

Desain kulit buku teks pelajaran IPS Kurikulum 2013 kelas VII SMP/MTS penerbit Platinum telah menampilkan unsur tata letaknya. Buku tersebut telah menampilkan sudut pandang yang baik seperti adanya gambar keindahan pemandangan alam yang ada di Indonesia (lautan, bukit dan gunung), serta terdapat gambar bola dunia (globe) di sampul belakang.

Warna kulit dan desain buku ini juga bisa memperjelas fungsi tulisan seperti warna putih dengan tulisan warna hijau, biru dan hitam untuk tulisan judul buku. Warna hitam untuk nama penulis, dan warna perak (silver) untuk nama penerbit yang ke semua warna itu mempunyai makna tersendiri dalam penyajian buku teks tersebut. Unsur tata letaknya telah sesuai dengan standar isi, seperti diawali dengan nama penulis, judul buku, untuk siapa buku itu digunakan, dan nama penerbitnya.

Pada buku teks pelajaran IPS Kurikulum 2013 Kelas VII SMP/MTs penerbit Platinum. Menurut penulis, desain isi buku yang ada dalam buku teks tersebut telah bisa dikatakan sesuai dengan standar yang ada. Mulai dari tata letak isi buku, tipografi isi buku, dan ilustrasi isi buku sudah memenuhi standar untuk sebuah buku teks pelajaran.

Dalam aspek kelayakan kegrafikaan, dari beberapa subkomponen dan butir analisis sesuai dengan pendapat Abdul Majid (2006: 176) yang memaparkan bahwa "buku yang baik adalah buku yang ditulis dengan menggunakan bahasa yang baik dan mudah dimengerti, disajikan secara menarik dilengkapi dengan gambar dan keterangan-keterangannya, isi buku juga menggambarkan sesuatu yang sesuai dengan ide penulisnya". Selanjutnya, menurut Yochanna (2009: 144) menitikberatkan "siswa sebagai pertimbangan guru dalam memilih buku pelajaran, yaitu: (1) kebutuhan siswa, (2) hal yang membuat siswa tertarik, dan (3) kemampuan siswa.

\section{E. Diskusi Model Keterpaduan IPS dalam Buku Teks Pelajaran IPS Kelas VII SMP/MTs Kurikulum 2013}

Berdasarkan hasil analisis isi model keterpaduan IPS dalam buku tersebut, pada kelima tema yang ada yaitu: (1) letak wilayah dan pengaruhnya bagi keaadaan alam Indonesia, (2) potensi dan sebaran sumber daya alam Indonesia, (3) penduduk Indonesia dan pemanfaatan potensi sumber daya alam, (4) keragaman sosial dan budaya Indonesia, dan (5) interaksi manusia dan lingkungan.

Pada tema letak wilayah dan pengaruhnya bagi keadaan alam Indonesia, mater pada buku ini tercakup dalam disiplin ilmu geografi. Contohnya adalah banyak materi yang dikembangkan secara geografis dari tema tersebut yaitu. Gambar peta letak astronomis dan letak 
geografis yang disajikan, batas negara Indonesia dengan negara lain hingga materi tentang cuaca, iklim sampai flora dan fauna. Pada tema ini juga dikembangkan materi secara ekonomi seperti pada subtema konektivitas antarruang waktu terdapat materi kegiatan ekonomi, hubungan produksi, konsumsi dan distribusi. Pada tema ini juga dikembangkan materi pada disiplin ilmu sosiologi dan sejarah yang terdapat pada subtema kehidupan sosial masanyarakat Indonesia pada masa praaksara, hindubuddha hingga masa islam. Yang pada materi tersebut terdapat interaksi sosial manusia pada masa itu dan sejarah peradaban atau kehidupan manusia pada masamasa tersebut.

Pada tema potensi dan sebaran sumber daya alam Indonesia ini memang sangat identic dengan ilmu geografi. Pada tema ini materi yang dikembangkan lebih banyak kepada aspek geografi, seperti materipengertian tanah dan jenisnya, pengertian air dan jenisnya, tambang, hutan. Namun juga sedikit dikembangkan materi kearah sejarah, ekonomi dan sosiologi. Hal ini bisa dilihat dari kolom pengayaan yang terdapat materi tentang sumber daya alam yang bisa dijadikan tempat wisata dengan pemandangan indahnya seperti Danau Toba, Taman Nasional Baluran, Ngarai Sianok, Kepulauan Raja Ampat, Gunung Rinjani dll.

Pada tema ketiga yaitu penduduk Indonesia dan pemanfaatan potensi sumber daya alam Indonesia juga berdasarkan disiplin ilmu geografi dengan sub-sub tema yang terdapat pada buku ini meliputi materi keadaan penduduk Indonesia dengan materi pelajaran tentang jumlah penduduk di Indonesia, komposisi penduduk di Indonesia berdasarkan beberapa kriteria. Pada subtema selanjutnya terdapat materi pertumbuhan penduduk, jenis-jenis pertumbuhan penduduk, proyeksi penduduk, dan kepadatan penduduk.

Aspek sosiologi dikembangkan pada subtema kualitas penduduk Indonesia,yang berisi materi tentang pendidikan, kesehatan dan pendapatan.Pada subtema terakhir juga berisi materi dari aspek sosiologi, seperti materi tentang lembaga-lembaga sosial yang terdiri dari pengertian dan fungsi lembaga sosial, jenis lembaga sosial (lembaga keluarga, lembaga pendidikan, lembaga agama, lembaga ekonomi dan lembaga politik),lalu terdapat materi mobilitas penduduk tentang migrasi.

Pengembangan materi aspek ekonomi terdapat pada subtema pemanfaatan sumber daya alam terdapat materi tentang penggunaan lahan di perdesaan, penggunaan lahan di perkotaan (perdagangan, perkantoran, permukiman, ruang hijau terbuka, kawasan industry dll). Pada subtema potensi alam dan mobilitas penduduk antar wilayah di Indonesia berisi materi tentang pengertian pertanian, perkebunan, peternakan, perikanan, kehutanan, pertambangan, perindustrian, dan sector jasa. Namun pada tema ketiga ini tidak ditemukan materi yang dikembangkan dari aspek sejarah.

Pada tema empat, aspek gografi memang bukan menjadi tema utama pada tema keragaman sosial dan budaya Indonesia, karena aspek sejarah dan sosiologi yang banyak dikembangkan pada tema kali ini seperti menjelaskan asal-usul nenek moyang suku bangsa Indonesia, keragaman dan perkembangan kehidupan suku bangsa di Indonesia, pengertian dan proses interaksi dan sosialisasi, keragaman dan perkembangan suku bangsa, perkembangan peran dan status sosial (ascribed status dan achieved status).

Pada subtema keragaman nilai sosial dan seni budaya di Indonesia materi yang dibahas adalah nilai sosial dan norma sosial, keragaman hasil seni budaya yang berisi tentang bangunan masa prasejarah di Indonesia, interaksi masyarakat di berbagai daerah dengan tradisi hindu Buddha, ciri-ciri arsitektur bangunan hindu-buddha, peninggalan sejarah kerajaan islam, perkembangan pendidikan, kesenian, dan kesusasteraan di kerajaan islam di Indonesia.

Namun pada tema keempat ini aspek geografi dan ekonomi juga dikembangkan walaupun tidak banyak namun ada seperti pada subtema faktor yang memengaruhi keragaman sosial budaya membahas tentang kondisi geografis, dan kepercayaan. Hingga sub tema terakhir tentang keragaman budaya sebagai asset perekonomian bangsa yang membahas tentang sikap kreatif dan sikap mandiri.

Pada tema yang terakhir di buku ini yaitu interaksi manusia dan lingkungan juga dikembangkan dari aspek geografi namun lebih materi pembelajarannya lebih banyak dikembangkan dengan aspek ekonomi, sosiologi dan sejarah. Seperti pada materi menjelaskan interaksi manusia dengan lingkungan, keterkaitan antar komponen lingkungan, dampak aktivitas manusia terhadap lingkungan alam, dampak ativitas manusia terhadap lingkungan ekonomi, dan dampak aktivitas manusia terhadap sosial budaya.

Aspek sejarah, antropologi dan sosiologi terlihat pada materi interaksi manusia dan lingkungan, interaksi manusia dan lingkungan pada masa praaksara, masa hindu-buddha dan pada masa islam. Pada materi pengayaan terdapat beberapa bentuk interaksi sosial dalam kehidupan masyarakat seperti (kerjasama, akomodasi, asimilasi, persaingan, kontraversi dan pertentangan). subtema terakhir berisi materi dampak aktivitas manusia terhadap lingkungan sosial budaya. Aspek ekonomi dikembangkan pada subtema 4 yang membahas materi tentang dampak aktivitas manusia terhadap lingkungan ekonomi.

Sedangkan aspek geografi terdapat pada subtema saling keterkaitan antarkomponen lingkungan, dampak aktivitas manusia terhadap lingkungan alam (kerusakan hutan, kerusakan tanah, dan pencemaran air, pencemaran udara, dan penemaran tanah).

\section{PENUTUP}

\section{Simpulan}

Berdasarkan hasil penelitian dan pembahasan dapat disimpulkan bahwa buku teks pelajaran Ilmu Pengetahuan Sosial Kelas VII SMP/MTs Kurikulum 2013 terbitan Platinum sudah menenuhi standar (mutu) kelayakan dari BSNP. Berdasarkan aspek kelayakan isi, buku tersebut untuk uraian materi sudah sesuai dengan KI dan KD, keakuratan materi juga sudah sesuai walaupun ada satu ilustrasi yang tidak 
mencantumkan sumbernya, untuk kemutakhiran materi, mendorong keingintahuan, dan peluasan wawasan juga sesuai dengan deskripsi standar penilaian dari BSNP.

Menurut aspek kelayakan penyajian juga sudah sesuai dengan deskripsi dari teknik penyajian, pendukung penyajian, dan penyajian pembelajaran walaupun dengan beberapa hal yang harus diperbaiki seperti glosarium dan data indeks. Sedangkan untuk aspek kelayakan Bahasa sebagian besar sudah layak sesuai dengan deskripsi dari kesesuaian dengan tingkat perkembangan peserta didik, komunikatif, dan tata Bahasa, ejaan, istilah dan simbol. Untuk aspek yang keempat yaitu kegrafikaan, dari butir-butir yang dinilai mulai ukuran buku, desain kulit buku dan desain isi buku. Buku teks tersebut telah memenuhi standar kelayakan kegrafikan yang telah ditentukan oleh BSNP.

Sedangkan berdasarkan model keterpaduan IPS. Materi yang terdapat pada buku tersebut sudah mengembangkan model keterpaduan IPS secara integrated berdasarkan topic atau tema. Pada kelima tema yang ada di buku tersebut materi-materi dibidang ilmu geografi, sejarah, sosiologi dan ekonomi sudah disajikan sebagai satu kesatuan dalam mata pelajaran IPS

\section{Saran}

Oleh karena buku teks pelajaran merupakan salah satu , maka peneliti menyarankan hal-hal sebagai berikut.

1. Buku teks pelajaran adalah acuan wajib untuk digunakan di sekolah maka harus disusun berdasarkan standar nasional pendidikan.

2. Buku teks pelajaran harus memenuhi kriteria mutu (standar) buku teks pelajaran yaitu aspek kelayakan isi/materi, aspek kelayakan penyajian, aspek kelayakan bahasa, dan aspek kelayakan kegrafikaan.

3. Dilakukan penilaian buku teks secara berkala oleh BSNP demi tersedianya buku teks pelajaran layak pakai untuk meningkatkan mutu pendidikan nasional, meningkatkan mutu sumberdaya perbukuan Indonesia, melindungi peserta didik dari buku-buku yang tidak berkualitas dan meningkatkan minat dan kegemaran membaca.

4. Bagi para penulis buku teks terutama buku teks IPS supaya dalam menyusun buku teks pelajaran IPS mengikuti kaidah atau standar yang ditetapkan oleh BSNP dan model keterpaduan dalam pembelajaran IPS.

\section{DAFTAR PUSTAKA}

Adisendjaja. Y.H \& Romlah, O. (2011). Analisis buku ajar sains berdasarkan literasi ilmiah sebagai dasar untuk memilih buku ajar sains (biologi). Bandung: UniversitasPendidikan Indonesia.

A.Goltash, M. Salehi, A. Bazrafshan, \& S. Mohammadjani. (2014). "A critical analysis of the progressive citizenship education approach in social studies textbooks in the iranian middle school". International Journal of Humanities and Manajemen sciences. Vol 2 No. 2, pp. 58-60.

Ahour, T., Towhidiyan, B., \&Saeidi, M. (2014). "The evaluation of "english textbook 2 " taught in iranian high schools from teachers' perspectives". English Language Teaching. Vol. 7, No. 3.

Al-Ghazo, A., \&Smadi, O.M. (2013). "A content analysis of the english reading text's authenticity in student's book of action pack eleven in jordan". European Scientific Journal. Vol.9, No.29.

Azarfam, A.A.Y. (2014). "Evaluating an english textbook for aplication in iranianefl academic context". Theori and Practice in Language Studies. Vol. 4, No. 3, pp. 618-623.

Bahare Babaei, \& Ali Abdi. (2014). "Textbooks content analysis of social studies and natural sciences of secondary school based on emotional intelligence components". Universal Journal of Educational Research. Vol 2 No. 4, pp. 309-325.

B. Salmani, R. Hakimzadeh, M. Asgari\& S.A. Khaleghinezhad. (2015) "Environmental education in iranian school curriculum, a content analyses of social studies and science textbooks". International Journal Environmet Research. Vol 9 No. 1 Winter 2015, pp. 151-156.

Bryd, P. (2001). Textbook: evaluation for selection and analysis for implementation. Dalam Murcia, M.C (Ed), Teaching English as a second or foregn language $\quad 3^{\text {rd }}$ ed (pp. 416-418). Boston: Heinle\&Heinle.

BSNP. (2006). Model kurikulum tingkat satuan pendidikan untuk sekolah menengah pertama. Jakarta : BSNP.

Gabrielatos, C. (2004). Session plan: the coursbook as a flexible tool. Dalam IATPL Teacher Trainers and Educators SIG Newsletter I/2004 (pp2831)diambil pada tanggal 1 Maret 2015 dari http://www.gabrielatos.com.//CB-Use-TTED.Pdf

Fajar, A. (2005). Portofolio dalam pembelajaran ips. Bandung: Remaja Rosdakarya.

Harmer, J. (2007). The practice of english language teaching $4^{\text {th }} e d$. London: Longman.

Hedgcock, J.J \& Ferris, D.R. (2009). Teaching readers of english. student text and context. New York: Madison Ave.

Igbaria, A.K (2013) ."A content analysis of the whquestions in the efl textbook of horizons". International Education Studies. Vol. 6, No. 7.

Kemendikbud. (2013). Peraturan menteri pendidikan dan kebudayaan nomor 54, tahun 2013, tentang standar isi pendidikan dasar dan menengah.

. (2013). Peraturan menteri pendidikan dan kebudayaan nomor 67, tahun 2013, tentang perubahan atas peraturan pemerintah nomor 19 tahun 2005 tentang standar nasional pendidikan. 
Khus Bakht Hina, Muhammad Ajmal, Fazarul Rahman, \&Nabi Bux Jumani. (2011). "State of citizenhip education: a case study from pakistan". International Journal of Humanities and Social Science. Vol 1 No. 2, pp. 37-43.

Krippendorf, K. (2004). Content analysis: an introduction to its methodology, $(E d)$. Thousand Oaks: Sage Publication Ltd.

Majid, A. (2006). Perencanaan pembelajaran mengembangkan standar kompetensi guru, Bandung : PT Remaja Rosdakarya.

Marzieh Shujahuddini Bazanjani, Firoz Rezayian, Abbas Anarinezhad, \&Tahereh Nasabpour Molaei (2015). "The content analysis of the elementary school social civics textbooks regarding the components of citizenship education". Sai $\mathrm{Om}$ Journal of Art \& Education. Vol 1 No. 12, pp. 2837.

Mulhayati, B. (2014). Analisis buku tematik terpadu kurikulum 2013 kelas iv sekolah dasar. (Tesis). Universitas Pendidikan Indonesia.

Muslich, M. (2010). Text book writing: dasar-dasar pemahaman, penulisan, dan pemakaian buku teks. Yogyakarta: Ar-Ruzz Media.

Nasution. (2011). Kajian pembelajaran ips di sekolah. Surabaya: Unesa University Press.

NCSS. (1994). Expectation of excellence: curriculum standards for social studies. Washington: NCSS.

Peraturan Pemerintah Nomor 10 Tahun 2010 Tentang pengelolaan dan Penyelenggaraan Pendidikan.

Rennie J. Moon \&Jeong Woo Koo. (2011). “Global citizenship and human right: analysis of social studies and ethnic textbooks in the republic of korea". Comparative and International Education Society. Vol 55 No. 4, pp. 574-596.

Safdar R. Ghazi, Gulap Shahzada, Ismail Khan, M. Nauman Shabbir, \& M. Tahir Shah. (2011). "Content analysis of textbooks of social and pakistan studies for religious tolerance in pakistan”. Asian Social Science. Vol 7 No.5, pp. 124-149.

Sapriya. (2009). Pendidikan ips: konsep dan pembelajaran. Bandung: Remaja Rosdakarya.

Sitepu, B.P, (2012). Penulisan buku teks pelajaran, Bandung: PT RemajaRosdakarya.

Sumantri, M. N. (2001). Menggagas pembaharuan pendidikan ips. Bandung: Remaja Rosdakarya.

Tarigan, H.G. dan Djago Tarigan. (2009). Telaah buku teks bahasa indonesia. Bandung: Angkasa.

Tim Penyusun KBBI. (2005). Kamus besar bahasa Indonesia edisi ketiga. Jakarta: Balai Pustaka.

Undang-Undang Dasar Negara Kesatuan Republik Indonesia Tahun 1945.

Undang-Undang Republik Indonesia Nomor 20Tahun 2003 tentang Sistem Pendidikan Nasional.

Wina Sanjaya. (2008). Kurikulum dan pembelajaran. Jakarta: Kencana Pranada Media Group. 